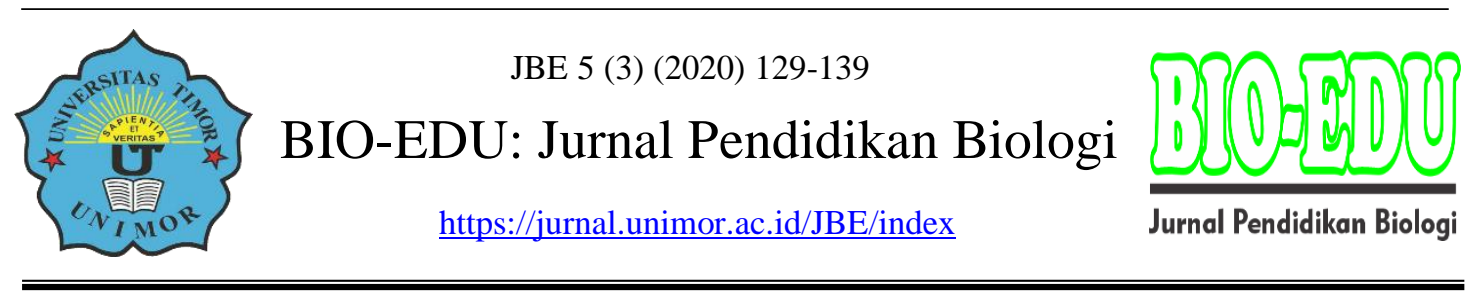

\title{
Diversity of Zooplankton in Lindu Lake Waters Central Sulawesi Province
}

\section{Keanekaragaman Zooplankton di Perairan Danau Lindu Provinsi Sulawesi Tengah}

\author{
Siti Hartina ${ }^{1}$, Manap Trianto ${ }^{2}$ \\ ${ }^{1}$ Program Studi Pendidikan Biologi, Fakultas Keguruan dan Ilmu Pendidikan, \\ Universitas Tadulako \\ ${ }^{2}$ Fakultas Biologi, Universitas Gadjah Mada \\ E-mail: sitihartina103@gmail.com
}

DOI: https://DOI 10.32938/jbe. v5i3.728

\begin{abstract}
Abstrak
Zooplankton adalah hewan-hewan kecil yang berenang atau mengapung di kolam air dan sangat mempengaruhi kehidupan organisme perairan danau terutama sebagai pakan alami dalam pengembangan dan pembudidayaan ikan. Tujuan penelitian ini adalah untuk menentukan keanekaragaman jenis Zooplankton di Perairan Danau Lindu. Penelitian ini dilaksanakan pada bulan April - Juni 2019 dengan menggunakan metode purposive sampling. Hasil identifikasi diperoleh 9 jenis Zooplankton di perairan Danau Lindu Provinsi Sulawesi Tengah, yaitu Daphnia sp, Epischura lacustris, Hyperia sp, Cyclops vicinus, Pseudophausia sp, Temora sp, Alonella dadayi, Nebela caudate, Brachionys havanaensis. Keanekaragaman jenis Zooplankton yang di dapatkan di Perairan Danau Lindu yaitu 2,190 (Tingkat keanekaragaman sedang). Nilai H' tertinggi terdapat pada stasiun III (Inlet) yaitu 2,175 dan nilai H' terendah terdapat pada stasiun II (Pemukiman) sebesar 2,149.
\end{abstract}

Kata Kunci: Keanekaragaman; Zooplankton; Danau Lindu; Sulawesi Tengah; Lingkungan

\begin{abstract}
Zooplankton is small animals that swim or float in water pools and significantly affect the life of lake aquatic organisms, especially as natural food for the development and cultivation of fish. The purpose of this study was to determine the species diversity of Zooplankton in Lake Lindu. This research was conducted from April to June 2019 using a purposive sampling method. There were nine species of Zooplankton found in Lake Lindu, Central Sulawesi Province, namely Daphnia sp, Epischura lacustris, Hyperia sp, Cyclops vicinus, Pseudophausia sp, Temora sp, Alonella dadayi, Nebela caudate, Brachionys havanaensis. The diversity of Zooplankton species found in the waters of Lake Lindu is 2.190 (moderate diversity level). The highest $\mathrm{H}$ value is at station III (Inlet) which is 2.175 , and the lowest $\mathrm{H}$ 'value is at station II (settlements) of 2.149.
\end{abstract}

Keywords: Diversity; Zooplankton; Lindu Lake; Central Sulawesi; Environmenta 


\section{PENDAHULUAN}

Wilayah Indonesia memiliki banyak perairan danau yang dihuni oleh beraneka sumber daya hayati perairan seperti ikan dan biota lainnya. Luas perairan danau di Indonesia $\pm 2,1$ juta $\mathrm{Ha}$ (danau alami dan buatan), untuk daerah Sulawesi Tengah terdapat perairan danau seluas 29,238 Ha (Kusmeri dan Rosanti, 2015: 7-17; Trianto dan Purwanto, 2020: 186-193; Trianto dan Purwanto, 2020: 2619-2628).

Provinsi Sulawesi Tengah merupakan salah satu provinsi yang berada di Pulau Sulawesi Indonesia, memiliki banyak pulau dan danau yang tersebar luas dari Kabupaten Morowali bagian selatan sampai Kabupaten Buol bagian utara. Luas wilayah darat meliputi $61.841,29 \mathrm{~km}^{2}$ serta jumlah pulau sebanyak 1.134 pulau (Berdasarkan hasil verifikasi pulau tahun 2008) atau sekitar 38 persen dari luas wilayah Sulawesi (Batubara et al., 2014: 25-40; Trianto et al., 2020: 199-209). Informasi keberadaan danau mungkin tidak semua diketahui secara luas oleh masyarakat di Provinsi Sulawesi Tengah, terlebih masyarakat Indonesia bahkan dunia, padahal banyaknya danau di Provinsi Sulawesi Tengah mempunyai keunikan serta keindahan alamnya, posisi yang strategis serta mempunyai keunggulan sumber daya potensial yang dikembangkan untuk beragam kegiatan ekonomi (Batubara et al., 2014: 23-27; Trianto et al., 2020: 21-29). Selain itu terdapat keunikan budaya masyarakat yang tinggal di sekitarnya, juga biota dan fauna endemik yang hidup di dalamnya, salah satu danau yang terdapat di Sulawesi Tengah adalah Danau Lindu.

Danau Lindu berdasarkan geografisnya terletak di Kecamatan Lindu, Kabupaten Sigi, Provinsi Sulawesi Tengah. Danau ini berada pada kawasan Taman Nasional Lore Lindu. Taman Nasional ini ditetapkan oleh Menteri Kehutanan tahun pada 1999 mempunyai luas $217.991 \mathrm{Ha}$ dan berada pada ketinggian $500-3.000 \mathrm{~m}$ di atas permukaan laut, dengan posisi geografis $1^{\circ} 3^{\prime}$ - $1^{\circ} 58^{\prime}$ Lintang Selatan, $119^{\circ} 57^{\prime}-120^{\circ} 22^{\prime}$ Bujur Timur. Danau Lindu memiliki luas permukaan 3.447,4 Ha dengan kelililing 26,5 km panjang maksimum 9,6 km, lebar maksimumnya 4,8 km, kedalaman maksimum danau Lindu yaitu $72,6 \mathrm{~m}$. Untuk berbagai kepentingan masyarakat yang berada di dalam kawasan Taman Nasional Lore Lindu, maka tepatnya pada tahun 1980-1981 kawasan Danau Lindu dan perkampungan sekitarnya ditetapkan sebagai Enclave Lindu dan tidak termasuk kawasan hutan lindung lagi. Danau sebagai satu kesatuan (ekosistem) memiliki daya dukung yaitu kemampuan perairan danau untuk mendukung secara layak kehidupan secara layak kehidupan suatu organisme. Tinggi rendahnya daya dukung perairan dapat dilihat dari tingkat kesuburan perairan. Salah satu faktor lingkungan yang dapat mempengaruhi kehidupan organisme perairan seperti udang, ikan, dan organisme perairan lainnya adalah Zooplankton yang merupakan sumber makanan alami perairan (Lukman dan Ridwansyah, 2003: 11-20; Trianto et al., 2020: 154-162).

Menurut Fitriya dan Lukman (2013: 219-227) pemanfaatan perairan danau untuk berbagai kepentingan masyarakat akan memberikan efek buruk terhadap kelestarian danau dan biota didalamnya, jika tidak memperhatikan struktur dasar ekosistemnya. Pemanfaatan bersama perairan danau pada sektor-sektor pembangunan disatu pihak telah menunjukkan hasil yang menggembirakan, tetapi dilain pihak pula telah menimbulkan berbagai bentuk tekanan dan ancaman terhadap sumber daya dan lingkungannya, serta seluruh biota termasuk ikan dan organisme plankton. 
Nedi (2003: 1-3) menyatakan bahwa plankton merupakan salah satu sumber makanan alami ikan yang tersedia diperairan. Keberadaan Plankton baik Fitoplankton maupun Zooplankton sangat mempengaruhi kehidupan organisme perairan danau. Seperti yang diketahui pentingnya peran plankton diperairan danau terutama sebagai pakan alami dalam pengembangan dan pembudidayaan ikan, maka dinilai perlu untuk melakukan penelitian tentang berbagai jenis plankton, baik Fitoplankton maupun Zooplankton diperairan Danau Lindu Kabupaten Sigi, karena dengan meneliti tentang plankton maka diketahui bahwa kondisi fisik dari lingkungan perairan tersebut masih dikatakan baik. Seperti penelitian yang dilakukan oleh Irfan (2016: 23-35) tentang Keanekaragaman Plankton di perairan Telaga Sibili Kelurahan Pantoloan Kecamatan Taweli, dengan hasil penelitian menunjukkan keanekaragaman masih dalam kategori sedang. Penelitian ini bertujuan untuk mempelajari keanekaragaman Zooplankton di Danau Lindu Provinsi Sulawesi Tengah. Hasil penelitian ini diharapkan dapat memberikan tambahan informasi tentang studi keanekaragaman Zooplankton yang berkaitan dengan faktor lingkungan serta dapat membantu dalam melakukan pengembangan ekosistem yang berkelanjutan.

\section{METODE}

\section{Waktu dan Tempat Penelitian}

Penelitian ini dilaksanakan dari bulan April sampai dengan Juni 2019 di Perairan Danau Lindu, Kabupaten Sigi, Provinsi Sulawesi Tengah. Kemudian dilanjutkan di Laboratorium Pendidikan Biologi FKIP UNTAD untuk mengidentifikasi Zooplankton yang tercuplik. Jenis penelitian ini adalah penelitian deskriptif, dengan menggunakan metode survey (penelitian di lapangan).

\section{Alat dan Bahan}

Alat yang digunakan yaitu termometer, $\mathrm{pH}$ meter, DO meter, keping secchi, kamera, plankton net, botol sampel, perahu, kertas label, mikroskop, pipet tetes, dan salinometer. Bahan yang digunakan yaitu sampel zooplankton, dan larutan FAA (Formalin, Asam asetat glasial, dan alkohol 70\%).

\section{Pelaksanaan Penelitian}

Penelitian ini terdiri dari empat tahap yaitu penentuan stasiun, pengukuran kondisi fisik dan kimia lingkungan, pengambilan sampel zooplankton, serta analisis data.

\section{Penentuan Stasiun}

Stasiun penelitian ditentukan berdasarkan pertimbangan kondisi lingkungan atau keadaan di perairan Danau Lindu. Berdasarkan keadaan tersebut maka ditetapkan lima stasiun penelitian yaitu Stasiun I (Perairan sekitar lokasi pemukiman warga), Stasiun II (Perairan sekitar lokasi dermaga), Stasiun III (Aliran masuk air), Stasiun IV (Perairan tengah danau), dan Stasiun V (Aliran keluar air). Selanjutnya, pengambilan sampel dilakukan pada setiap titik koordinat secara horizontal dengan waktu pengambilan sampel dilakukan pada pagi, siang, dan malam hari, dengan pegulangan sebanyak tiga kali. Pengukuran kondisi fisik dan kimia lingkungan

Mengambarkan kondisi fisik-kimia perairan Danau Lindu, dilakukan pengukuran dan pengambilan contoh (sampel) air pada setiap stasiun. Parameter yang diukur langsung 
di lapangan adalah suhu air dengan menggunakan thermometer, kecerahan dengan keping secchi, $\mathrm{pH}$ air dengan menggunakan $\mathrm{pH}$-meter, dan oksigen terlarut dengan menggunakan DO-meter.

Pengambilan sampel zooplankton

Pengambilan sampel secara vertikal diambil pada kedalaman dibawah batas daerah transparansi, untuk menentukan daerah transparansi sebelumnya kita menjatuhkan keeping sechi (sechi disc). Hasil pengukuran daerah transparansi sedalam \pm 3 meter. Hasil pengukuran daerah transparansi sedalam \pm 3 meter. Berdasarkan pengukuran daerah transparansi tersebut sampel pada kedalaman setiap stasiun \pm 3 meter dibawah daerah transparansi dengan menggunakan net plankton, dengan cara menurunkan pada masingmasing kedalaman tersebut. Setelah beberapa menit net plankton sampling dijatuhkan dan menarik tali pembuka botol tersebut terisi penuh dengan air, kemudian net plankton tersebut ditarik keatas untuk memperoleh filtrate Plankton. Filtrate Plankton yang diperoleh dimasukkan kedalam botol koleksi atau botol sampel dan ditambah FAA sebanyak 2-3 tetes sebagai pengawet, selanjutnya dibawa ke Laboratorium untuk di identifikasi.

\section{Analisis Data}

Data keanekaragaman jenis-jenis Zooplankton dihitung berdasarkan rumus keanekaragaman jenis dari Shannon-Wiener.

Keterangan :

$$
\mathrm{H}^{\prime}=-\sum \mathrm{Pi} \text { In Pi }
$$

H' = Indeks Keanekaragaman Shannon-Wienner

ni = Jumlah individu satu jenis

$\mathrm{N}=$ Jumlah total individu semua jenis

$\mathrm{Pi} \quad=n i / \mathrm{N}$

Berdasarkan indeks keanekaragaman jenis menurut Shannon-Winner didefinisikan sebagai berikut:

Nilai H'> 3 menunjukkan bahwa keanekaragaman jenis adalah tinggi.

Nilai $\mathrm{H}^{\prime} \leq \mathrm{H}^{\prime} \leq 3$ menunjukkan bahwa keanekaragaman jenis adalah sedang.

Nilai H' $<1$ menunjukkan bahwa keanekaragaman jenis adalah sedikit atau rendah.

\section{HASIL DAN PEMBAHASAN}

\section{Hasil}

\section{Kondisi Fisik Kimia Lingkungan Perairan Danau Lindu}

Kondisi lingkungan baik secara fisik, kimia, dan biologis sangat diperlukan untuk mengetahui ciri-ciri suatu perairan, serta dapat dijadikan sebagai dasar untuk menetukan tercemar atau tidaknya perairan tersebut (Mamu, 2007; Trianto dan Marisa, 2020: 29-33). Kondisi fisik-kimia perairan Danau Lindu yang diukur, meliputi suhu $\left({ }^{\circ} \mathrm{C}\right), \mathrm{pH}$, oksigen terlarut (mg/1), salinitas (\%o), dan kecerahan (m). Berdasarkan hasil pengukuran yang telah di lakukan, diperoleh hasil yang bervariasi pada setiap stasiun pengamatan (Tabel $1)$. 
Tabel 1. Kondisi fisik kimia lingkungan Perairan Danau Lindu

\begin{tabular}{clcccccc}
\hline \multirow{2}{*}{ No } & \multicolumn{1}{c}{ Parameter } & I & II & III & IV & V & \multirow{2}{*}{ Rata-rata } \\
\cline { 3 - 6 } & Suhu Lingkungan $\left({ }^{\circ} \mathrm{C}\right)$ & 28,1 & 24,3 & 27,1 & 27,3 & 25,4 & 26,44 \\
\hline 1 & Suhu Air $\left({ }^{\circ} \mathrm{C}\right)$ & 23,4 & 25,1 & 23,5 & 23,3 & 23,8 & 23,82 \\
2 & 7,9 & 7,7 & 7,9 & 8,1 & 7,6 & 7,84 \\
3 & Ph & $1 \mathrm{~m}$ & $1 \mathrm{~m}$ & $0,5 \mathrm{~m}$ & $3,35 \mathrm{~m}$ & $1 \mathrm{~m}$ & 1,37 \\
4 & Kecerahan (m) & 0,4 & 0,2 & 0,5 & 0,3 & 0,2 & 0,32 \\
5 & Salinitas (\%o) & 6,3 & 5,2 & 6,6 & 6,5 & 6,2 & 6,16 \\
6 & Oksigen terlarut (mg/1) & & & & & & \\
\hline
\end{tabular}

\section{Jenis Zooplankton di Danau Lindu}

Berdasarkan hasil penelitian yang telah dilakukan pada lima stasiun pengamatan, secara keseluruhan ditemukan 9 spesies Zooplankton (Gambar 1) yang terdiri dari 7 Ordo, 6 Famili, dan 9 Genus (Tabel 2).

Tabel 2. Jenis-Jenis Zooplankton di Danau Lindu

\begin{tabular}{cllll}
\hline No & \multicolumn{1}{c}{ Ordo } & \multicolumn{1}{c}{ Famili } & \multicolumn{1}{c}{ Genus } & \multicolumn{1}{c}{ Spesies } \\
\hline 1 & Cladosera & Daphnidae & Daphnia & Daphnia sp. \\
2 & Calanioda & Termoridae & Epischura & Epischura lacustris \\
3 & Calanioda & Termoridae & Temora & Temora sp. \\
4 & Copepoda & Hyperiaceae & Hyperia & Hyperia sp. \\
5 & Cyclopoida & Cyclopidae & Cyclops & Cyclops vicinus \\
6 & Euphausida & Cyclopidae & Pseudophausia & Pseudophausia sp. \\
7 & Phyllopoda & Chydoridae & Alonella & Alonella dadayi \\
8 & Ploimida & Brachionidae & Nebela & Nebela caudate \\
9 & Ploimida & Brachionidae & Brachionus & Brachionus havanaensis \\
\hline
\end{tabular}
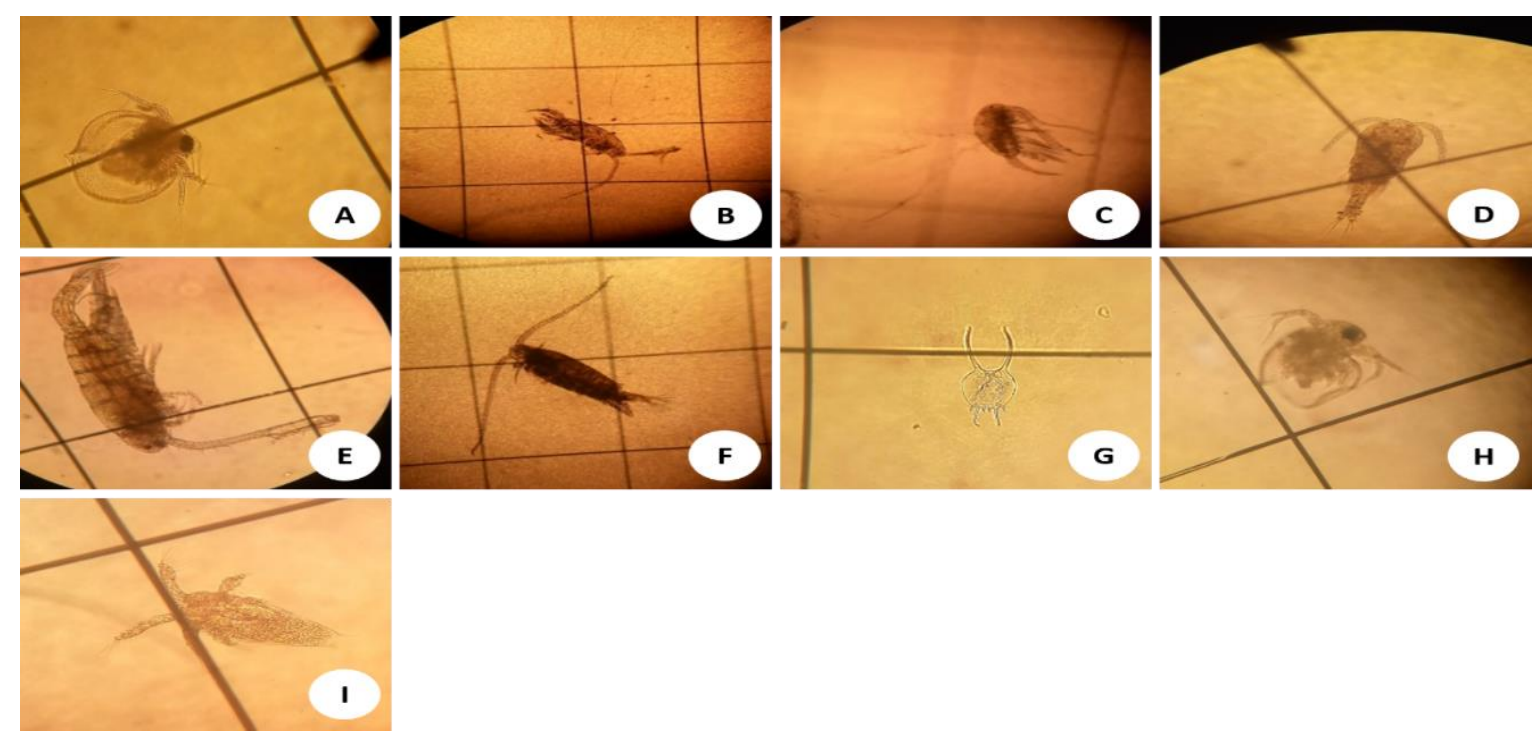

Gambar 1. Spesies Zooplankton di Danau Lindu: A. Daphnia sp., B. Epischura lacustris, C. Hyperia sp., D. Cyclops vicinus, E. Pseudophausia sp, F. Temora sp., G. Alonella dadayi, H. Nebela caudate, dan I. Brachionys havanaensis 


\section{Keanekaragaman Zooplankton di Danau Lindu}

Berdasarkan hasil penelitian yang dilakukan, ditemukan jumlah individu Zooplankton yang bervariasi pada setiap stasiun pengamatan. Variasi jumlah individu setiap jenis tersebut dapat dilihat pada Tabel 3.

Tabel 3. Jumlah individu Zooplankton di Danau Lindu

\begin{tabular}{|c|c|c|c|c|c|c|c|}
\hline \multirow{2}{*}{ No } & \multirow{2}{*}{ Jenis Zooplankton } & \multicolumn{5}{|c|}{ Stasiun } & \multirow{2}{*}{$\sum$} \\
\hline & & $\mathrm{I}$ & II & III & IV & $\mathrm{V}$ & \\
\hline 1 & Daphnia sp & 10 & 6 & 17 & 21 & 13 & 67 \\
\hline 2 & Epischura lacustris & 14 & 19 & 23 & 12 & 20 & 88 \\
\hline 3 & Temora sp & 13 & 8 & 15 & 20 & 10 & 66 \\
\hline 4 & Hyperia sp & 16 & 12 & 13 & 15 & 12 & 68 \\
\hline 5 & Cyclops vicinus & 10 & 15 & 26 & 11 & 11 & 73 \\
\hline 6 & Pseudophausia sp & 13 & 10 & 18 & 12 & 10 & 63 \\
\hline 7 & Alonella dadayi & 18 & 14 & 24 & 14 & 16 & 86 \\
\hline 8 & Nebela caudate & 9 & 11 & 19 & 18 & 10 & 67 \\
\hline 9 & Brachionus havanaensis & 8 & 11 & 18 & 15 & 13 & 65 \\
\hline & Total & 111 & 106 & 173 & 138 & 115 & 643 \\
\hline
\end{tabular}

Analisis tingkat keanekaragaman jenis Zooplankton di Danau Lindu menggunakan indeks keanekaragaman Shannon-Wienner. Dari hasil analisis yang telah dilakukan, diketahui bahwa Zooplankton yang terdapat di Danau Lindu memilik tingkat keanekaragaman $\mathrm{H}^{\prime}=2.190$ (sedang) (Tabel 4).

Tabel 4. Analisis indeks keanekaragaman Zooplankton

\begin{tabular}{lcccc}
\hline \multicolumn{1}{c}{ Jenis } & $\sum$ & $\mathrm{Pi}(\mathrm{ni} / \mathrm{N})$ & $\mathrm{In}(\mathrm{Pi})$ & $\mathrm{Pi}$ In Pi \\
\hline Daphnia sp & 67 & 0.104 & -2.261 & -0.236 \\
Epischura lacustris & 88 & 0.137 & -1.989 & -0.272 \\
Temora sp & 66 & 0.103 & -2.276 & -0.234 \\
Hyperia sp & 68 & 0.106 & -2.247 & -0.238 \\
Cyclops vinicus & 73 & 0.114 & -2.176 & -0.247 \\
Pseudophausia sp & 63 & 0.098 & -2.323 & -0.228 \\
Allonela dadayi & 86 & 0.134 & -2.012 & -0.269 \\
Nebela caudate & 67 & 0.104 & -2.261 & -0.236 \\
Brachionus havanaensis & 65 & 0.101 & -2.292 & -0.232 \\
\hline \multicolumn{1}{c}{ Total } & 643 & & & -2.190 \\
\multicolumn{1}{c}{ H' } & & & & 2.190 \\
\hline
\end{tabular}

\section{Pembahasan}

\section{Kondisi Fisik Kimia Perairan Danau Lindu}

Hasil pengukuran terhadap kondisi fisik kimia lingkungan Perairan Danau Lindu yang meliputi suhu, salinitas, $\mathrm{pH}$, kecerahan, dan oksigen terlarut pada setiap stasiun di peroleh hasil bervariasi seperti pada Tabel 1. Hasil pengukuran kisaran terhadap suhu perairan pada kelima stasiun tidak jauh berbeda, kisaran tersebut bersifat optimum (16- 
$36^{\circ} \mathrm{C}$ ) bagi kehidupan Zooplankton air tawar, dilihat dari kisaran suhu tersebut maka Perairan Danau Lindu mendukung untuk kehidupan Zooplankton. Hal ini didukung oleh pernyataan Augusta (2013: 68-74) untuk daerah tropis suhu berkisar $25-32^{\circ} \mathrm{C}$ adalah optimum bagi pertumbuhan ikan dan organisme lain diantaranya Zooplankton. Suhu merupakan faktor penting yang dapat mempengaruhi keberlangsungan Zooplankton diperairan. Tingkat respirasi akan semakin rendah seiring dengan peningkatan kekeruhan dan suhu.

Pengukuran salinitas yang dilakukan pada tiap-tiap stasiun yakni pada stasiun I diperoleh $0,4 \%$, stasiun II diperoleh $0,2 \%$, stasiun III diperoleh $0,5 \%$, stasiun IV diperoleh 0,3\% dan stasiun V diperoleh 0,2\% (Tabel 1). Sesuai pernyataan Nyabakken (1992: 68) bahwa nilai optimum salinitas air tawar berkisar 0-5\%. Berdasarkan kriteria tersebut, dapat dijelaskan bahwa tingkat salinitas di Perairan Danau Lindu masih dalam nilai normal untuk mendukung kehidupan Zooplankton.

Derajat keasaman $(\mathrm{pH})$ merupakan parameter yang digunakan untuk menentukan kadar asam/basa dalam air. Nilai pH menjelaskan nilai konsentrasi ion hidrogen pada suatu larutan. Nilai pH di Perairan Danau Lindu berkisar antara 7,6-8,1. Pada stasiun penelitian nilai $\mathrm{pH}$ yang diperoleh relatif normal. Akan tetapi pada stasiun I jumlah Zooplankton yang ditemukan tidak terlalu banyak. Hal ini disebabkan karena pada stasiun ini telah dijadikan sebagai tempat wisata, tempat pencucian motor, tempat pemancingan ikan dan sebagai tempat perkumpulan masyarakat pada sore hari. Dengan adanya aktifitas tersebut secara tidak langsung akan berpengaruh terhadap kualitas perairan yang ada disekitarnya sehingga dapat mempengaruhi kehadiran Zooplankton, meskipun nilai $\mathrm{pH}$ pada lokasi tersebut mendukung dan relatif normal. Pada umumnya nilai $\mathrm{pH}$ ideal yang dapat mendukung kehidupan organisme akuatik adalah 7-8,5 (Barus, 2004: 91-103).

Nilai kecerahan air berkisar antara 0,5-3,35 meter. Tingkat kecerahan ini masih tergolong tinggi dan memenuhi syarat bagi kehidupan organisme akuatik. Kecerahan air di bawah $100 \mathrm{~cm}$ termasuk dalam tingkat kecerahan yang rendah (Augusta, 2015: 30-35). Semakin dalam lapisan yang dapat ditembus sinar matahari maka perairan semakin cerah dan semakin baik pula suatu perairan. Odum (1994: 95-104) membagi kondisi perairan berdasarkan nilai transparansi yaitu perairan keruh (0,25-1,00 meter); perairan sedikit keruh $(1,00-5,00)$; perairan jernih $(>5$ meter). Berdasarkan pembagian tersebut, maka Perairan Danau Lindu termasuk dalam perairan keruh dengan tingkat sedang. Tingkat kecerahan tersebut sangat mendukung untuk kehidupan Zooplankton.

Nilai oksigen terlarut yang diukur selama penelitian berkisar 5,2-6,7 mg/l. Oksigen merupakan faktor pembatas bagi organisme perairan, karena kadar oksigen di perairan sangat terbatas dibandingkan di udara. Oksigen dibutuhkan dalam proses katabolisme dalam rangka menghasilkan energi untuk berbagai kebutuhan hidup. Atmosfer dan proses fotosintesis merupakan sumber utama oksigen terlarut. Oksigen dari udara akan diserap melalui proses difusi secara langsung di permukaan air oleh angin dan arus (Affan, 2011: 99-106). Setiap spesies biota akuatik mempunyai kisaran toleransi yang berbeda-beda terhadap konsentrasi oksigen terlarut disuatu perairan. Menurut Fuadi (2016: 169-176) konsentrasi terendah dari oksigen terlarut yang dibutuhkan oleh organisme perairan untuk keberlangsungan hidup adalah $1 \mathrm{ppm}$. Berdaarkan hal tersebut dapat diketahui bahwa kandungan oksigen terlarut di Perairan Danau Lindu masih cukup tinggi dan layak bagi kehidupan organisme di dalamnya temaksud Zooplankton. 
Berdasarkan hasil perhitungan keberadaan Zooplankton, yang meliputi keanekaragaman dan hasil pengkuran faktor lingkungan, dapat diketahui bahwa jumlah yang diperoleh antara stasiun I dengan stasiun yang lain memiliki nilai keanekaragaman yang berbeda. Dengan demikian dapat diketahui bahwa kegiatan masyarakat yang dilakukan di Perairan Danau Lindu belum memiliki dampak yang besar terhadap keanekaragaman Zooplankton.

\section{Jenis Zooplankton di Danau Lindu}

Hasil penelitian yang dilakukan di Perairan Danau Lindu dengan rona lingkungan yang heterogen, diperoleh 9 jenis Zooplankton yang terdiri dari 7 ordo, 6 famili, dan 9 genus. Adapun jenis Zooplankton tersebut adalah Daphnia sp, Epischura lacustris, Temora sp, Hyperia sp, Cyclops vicinus, Pseudophausia sp, Alonella dadayi, Nebela caudate, dan Brachionus havanaensis. Jenis Zooplankton yang ditemukan terdiri dari kelas Crustacea 4 jenis, kelas Maxillopoda 3 jenis, dan kelas Monogononta 2 jenis.

Jumlah spesies yang tercuplik pada tiap stasiun memiliki tingkat kehadiran yang berbeda, dimana pada stasiun I terdapat 111 individu yang tercuplik, pada stasiun II 106 individu, stasiun III 173 individu, stasiun IV 138 individu, dan pada stasiun V 115 individu (Tabel 3). Dari data tersebut dapat kita lihat bahwa terdapat perbedaan jumlah spesies pada tiap stasiun. Data tersebut menunjukkan bahwa faktor lingkungan pada tiap stasiun pengamatan masih dalam toleransi. Selain itu pada stasiun II tingkat kehadiran spesies lebih rendah dibanding dengan stasiun yang lainnya. Hal ini dapat dijelaskan karena stasiun II merupakan bagian perairan sekitar lokasi pemukiman yang mana bagian perairan tersebut banyak warga yang melakukan aktifitas. Pemanfaatan perairan seperti yang dikemukakan di atas tidak disadari telah menjadi penyebab perubahan lingkungan dan mengancam kehidupan organisme akuatik.

Faktor lain yang mempengaruhi banyaknya jumlah jenis Zooplankton yang didapatkan yaitu pada saat melakukan penelitian di Danau Lindu bertepatan dengan kegiatan adat yang dilakukan oleh beberapa Desa di Kecamatan Lindu. Kegiatan adat atau ombo adat melarang masyarakat melakukan aktifitas mengambil atau menangkap semua hewan di kawasan danau yang telah di tentukan yaitu 100 meter dari pinggir danau, sehingga pada saat penelitian terdapat sedikit hambatan khususnya pada saat pengambilan sampel, pengukuran sampel, dan pengambilan dokumentasi sampel sehingga dapat mempengaruhi jumlah Zooplankton yang diperoleh.

\section{Keanekaragaman Zooplankton di Danau Lindu}

Hasil keanekaragaman jenis Zooplankton yang didapatkan pada penelitian ini dapat dikategorikan sedang. Semakin rendah jumlah spesies dan variasi jumlah individu tiap spesies maka keanekaragaman suatu organisme disuatu ekosistem semakin kecil. Hal tersebut dapat mengakibatkan terjadinya ketidakseimbangan ekosistem gangguan atau tekanan dari lingkungan, berarti hanya jenis tertentu yang dapat bertahan hidup. Dari hasil perhitungan keanekaragaman yang di dapatkan di lokasi penelitian diperoleh hasil yang berbeda pada stasiun I sampai stasiun V.

Pada stasiun I yang berada pada sekitar area dermaga, indeks keanekaragamannya menunjukkan angka 2,173 atau berada pada kategori keanekaragaman sedang. Hal ini dapat terjadi karena pada stasiun I dijadikan sebagai tempat wisata, tempat pencucian 
motor, tempat memancing ikan, dan sebagai tempat perkumpulan masyarakat pada saat sore hari. Dengan adanya kegiatan-kegiatan masyarakat tersebut secara tidak langsung akan berpengaruh terhadap kualitas perairan danau dan dapat mempengaruhi kehadiran Zooplankton (Gazali et al., 2013: 1-8).

Pada stasiun II yang berada di sekitar pemukiman warga, indeks keanekaragamannya menunjukkan angka 2,149. Stasiun II merupakan stasiun yang memiliki nilai keanekagraman jenis yang paling rendah dibanding dengan stasiun-stasiun yang lain. Hal tersebut disebabkan pada stasiun II merupakan bagian perairan sekitar lokasi pemukiman. Perairan tersebut telah dijadikan tempat pembuangan sisa pencucian, mandi, dan berbagai aktifitas lain. Aktifitas tersebut, menjadi penyebab terjadinya pencemaran air dan perubahan lingkungan yang mengancam kehidupan organisme akuatik sehingga dapat mempengaruhi kelangsungan hidup Zooplankton disekitar area pemukiman. Nugroho (2006) menyatakan pencemaran air disuatu ekosistem akan menyebabkan berkurangnya keanekaragaman dan kelimpahan atau punahnya populasi organisme perairan seperti perifiton, benthos, dan plankton.

Pada staisun III sebesar 2,175 yang berarti keanekaragamannya dikategorikan sedang. Stasiun III terletak di inlet danau atau aliran masuknya air ke danau. Stasiun III menunjukkan indeks keanekaragaman yang paling tinggi dibanding stasiun lainnya. Hal ini dapat terjadi karena pada perairan ini lebih banyak ditumbuhi tanaman air tawar yaitu Hydrilla yang mendominansi disekitar area pengamatan sehingga dapat memberi manfaat bagi kehidupan organisme yang ada disekitarnya, khususnya untuk kelangsungan hidup Zooplankton. Pada perairan stasiun III kondisi lingkungan dapat menunjang kehidupan Zooplankton karena berbagai limbah yang berasal dari sekitar danau bagian pemukiman tidak mencapai perairan bagian inlet, dan kalaupun ada jumlahnya lebih sedikit dan tidak mempengaruhi kondisi fisik kimia perairan bagian inlet secara signifikan. Karena pada stasiun III ditumbuhi oleh Hydrilla, maka Fitoplankton yang merupakan produsen sumber energi bagi kehidupan organisme lainnya termasuk Zooplankton pun melimpah. Lukman (2014: 22-31) menyatakan bahwa kepadatan jenis Zooplankton disuatu perairan sangat bergantung pada jumlah fitoplankton yang tersedia, karena fitoplankton merupakan jenis makanan bagi zooplankton, dengan demikian keberadaan atau kelimpahan zooplankton yang tinggi di suatu perairan akan berbanding lurus dengan keberadaan fitoplanktonnya.

Pada stasiun IV terletak pada tengah danau yang menunjukkan nilai keanekaragaman 2,173 dan dapat dikategorikan sedang. Hal tersebut disebabkan karena pada stasiun IV merupakan bagian perairan sekitar tengah danau. Pada stasiun IV diduga jauh dari polutan-polutan yang terletak di pinggiran Danau Lindu, sehingga memungkinkan kelangsungan kehidupan organisme perairan air tawar dapat berkembangbiak dengan baik dan dapat menunjang kehidupan Zooplankton. Jika suatu perairan belum tercemar, maka di dalamnya terjadi keseimbangan jumlah plankton dan tidak ada jenis plankton yang bersifat toksin (Wahyudewantoro dan Haryono, 2013: 173178)

Pada stasiun V yang berada pada sekitaran outlet, indeks keanekaragamannya menunjukkan angka 2,168. Nilai keanekaragaman ini juga masih menunjukkan bahwa keanekaragamannya adalah sedang. Stasiun V merupakan muara danau yang mengalir menuju ke sungai. Akumulasi air danau yang menuju ke muara terdapat partikel seperti pasir yang terbawa oleh arus air sehingga terjadi pendangkalan dan memberikan dampak 
terhadap kehidupan Zooplankton di perairan. Selain itu, arus yang berada diarea sekitar penelitian juga cukup deras sehingga hal ini dapat mempengaruhi kondisi kehidupan Zooplankton di perairan danau. Odum (1998: 56-158) menyatakan pada perairan yang memiliki arus yang tinggi dapat mempengaruhi kehidupan Zooplankton dikarenakan organisme ini memiliki kemampuan gerak yang terbatas dan tidak dapat melawan arus sehingga perpindahannya bergantung pada gerakan air.

Jika diamati secara menyeluruh, antara stasiun satu dengan stasiun lain yang berada di Perairan Danau Lindu, maka nilai keanekaragaman Zooplankton pada setiap stasiun memiliki perbedaan dengan kisaran nilai keanekaragaman jenis antara 2,1492,175. Berdasarkan indeks Shannon-Wienner bahwa $H^{\prime} 1 \leq H^{\prime} \leq 3$ menunjukkan bahwa keanekaragaman jenis adalah sedang.

\section{KESIMPULAN DAN SARAN Kesimpulan}

Berdasarkan analisis data keanekaragaman jenis Zooplankton pada lima stasiun di peraian danau Lindu Provinsi Sulawesi Tengah, diperoleh bahwa dari stasiun I sampai dengan stasiun V memiliki rata-rata nilai keanekaragaman Zooplankton sedang yaitu H' $=2,190$.

\section{Saran}

Perlu dilakukan penelitian lanjutan mengenai struktur komunitas Zooplankton pada Perairan Danau Lindu dan Perairan Danau lainnya di Provinsi Sulawesi Tengah. Hal ini secara tidak langsung berguna untuk mengetahui kualitas perairan danau.

\section{DAFTAR RUJUKAN}

Affan, J.M. (2011). Seleksi lokasi pengembangan budidaya dalam keramba jaring apung berdasarkan faktor lingkungan dan kualitas air di Perairan Pantai Timur Kabupaten Bangka Tengah. Jurnal Sains MIPA, 17(3), 99-106

Augusta, T.S. (2013). Struktur komunitas zooplankton di Danau Hanjalutung berdasarkan jenis tutupan vegetasi. Jurnal Ilmu Hewani Tropika, 2(2): 68-74.

Augusta, T.S. (2015). Analisis hubungan kualitas air terhadap komunitas zooplankton dan ikan di Danau Hanjalutung. Jurnal Ilmu Hewani Tropika, 3(2), 30-35.

Barus, (2004). Proposal Penelitian Skripsi Keanekaragaman dan Kelimpahan Zooplankton. Jakarta: UI Press.

Batubara, R.M.S.M., Yusuf, M., Sidqi, S.B., Sinaga, Y.B., \& Anang. (2014). Selat Sulawesi dan Selat Makassar. Jakarta: Kompas.

Fitriya, N., \& Lukman M. (2013). Komunitas zooplankton di Lamarela dan Laut Sawu Nusa Tenggara Timur. Jurnal Ilmu dan Teknologi Kelautan, 5(1), 219-227.

Fuadi, Z. (2016). Hubungan panjang berat ikan yang tertangkap di Krueng Simpoe, Kabupaten Bireun, Aceh. Jurnal Ilmiah Mahasiswa Kelautan dan Perikanan Unsyiah, 1(1), 169-176.

Gazali, I., Widiatmono, Rahadi, B., \& Wirosoedarmo, R. (2013). Evaluasi pencemaran air dampak pembuangan limbah cair pabrik kertas terhadap kualitas air sungai 
Klinter Kabupaten Nganjuk. Jurnal Keteknikan Pertanian Tropis dan Biosistem, $1(2), 1-8$.

Irfan, R. (2016). Keanekaragaman plankton di Perairan Telaga Sibili Kelurahan Pantoloan Kecamatan Tawaeli. [Skripsi]. Palu: Universitas Tadulako.

Kusmeri, L., \& Rosanti, D. (2015). Struktur komunitas zooplankton di Danau Opi Jakabaring Palembang. Jurnal PGRI Palembang, 12(1), 7-17.

Lukman, \& Ridwansyah. (2003). Kondisi daerah tangkapan dan ciri morfometri Danau Lindu. Jurnal Oseanologi dan Limnologi Indonesia, 35(2), 11-20.

Lukman. (2014). Efektivitas pemberian akar tuba (Derris elliptica) terhadap lama waktu kematian ikan nila (Oreochromis nilloticus). Jurnal Pertanian, 5(1), 22-31.

Mamu, H.D. (2007). Keanekaragam dan Distribusi Ikan Air Tawar di Perairan Danau Talaga Kabupaten Donggala Sulawesi Tengah. [Skripsi]. Palu: Universitas Tadulako.

Nedi, S. (2003). Input nutrien dan distribusinya di estuaria Sungai Siah. Jurnal Perikanan dan Kelautan, 3(2), 1-3.

Nugroho. (2006). Bioindikator Kualitas Air. Jakarta: Universitas Trisakti Press.

Nybakken, J.W. (1992). Biologi Laut Suatu Pendekatan Ekologis. Jakarta: PT Gramedia.

Odum, E.P. (1994). Dasar-Dasar Ekologi. Yogyakarta: Gadjah Mada Press.

Odum, E.P. (1998). Dasar-Dasar Ekologi. Edisi Keempat. Yogyakarta: Gadjah Mada Press.

Suprianto, Trianto, M., Alam, N., \& Kirana, N.G.A.G.C. (2020). Karakter morfologi dan analisis daerah conserved gen elongation factor 1a (EF1a) pada Lepidotrigona terminata. Jurnal Metamorfosa, 7(2), 30-39.

Trianto, M., \& Marisa, F. (2020). Diversity of bees and wasp (Hymenoptera) in cowpea (Vigna sinensis L.) in agricultural area at Martapura District, Banjar Regency, South Kalimantan. Journal of Science and Technology, 9(2), 29-33.

Trianto, M., \& Purwanto, H. (2020). Molecular phylogeny of stingless bees in the Special Region of Yogyakarta revealed using partial 16S rRNA mitochondrial gene. Buletin Peternakan, 44(4), 186-193.

Trianto, M., \& Purwanto, H. (2020). Morphological characteristics and morphometrics of Stingless Bees (Hymenoptera: Meliponini) in Yogyakarta, Indonesia. Biodiversitas, 21(6), 2619-2628.

Trianto, M., Kaini, Saliyem, Warsih, E., \& Winarsih. (2020). Keanekaragaman serangga polinator pada tanaman nanas (Ananas comosus (L.) Merr.) di Desa Bincau. Jurnal Penelitian Science dan Pendidikan, 9(2), 154-162.

Trianto, M., Marisa, F., \& Siswandari, N.P. (2020). Kelimpahan nisbi, frekuensi, dan dominansi jenis lalat di beberapa Pasar Tradisional di Kecamatan Martapura. Jurnal Metamorfosa, 7(2), 21-29.

Trianto, M., Marisa, F., \& Sukmawati. (2020). Keanekaragaman jenis rayap pada perkebunan kelapa sawit dan perkebunan karet di Kabupaten Banjar, Kalimantan Selatan. Jurnal Biologi Makassar, 5(2), 199-209.

Wahyudewantoro, G., \& Haryono. (2013). Hubungan panjang berat dan faktor kondisi ikan belanak (Liza subrividis) di perairan Taman Nasional Ujung KulonPandeglang, Banten. Jurnal Ilmu-Ilmu Hayati dan Fisik, 13(3), 173-178. 